\title{
Modeling weight loss of cheese during ripening and the influence of dairy system, parity, stage of lactation, and composition of processed milk
}

\author{
Claudio Cipolat-Gotet, ${ }^{1}{ }^{\oplus}$ Massimo Malacarne, ${ }^{1} \odot$ Andrea Summer, ${ }^{1 *} \odot$ Alessio Cecchinato, ${ }^{2} \odot$ \\ and Giovanni Bittante ${ }^{2}$ (D) \\ ${ }^{1}$ Department of Veterinary Science, University of Parma, 43126 Parma, Italy \\ ${ }^{2}$ Department of Agronomy, Food, Natural resources, Animals and Environment (DAFNAE), University of Padova, 35020 Legnaro (PD), Italy
}

\begin{abstract}
The yield, flavor, and texture of ripened cheese result from numerous interrelated microbiological, biochemical, and physical reactions that take place during ripening. The aims of the present study were to propose a 2-compartment first-order kinetic model of cheese weight loss over the ripening period; to test the variation in new informative phenotypes describing this process; and to assess the effects on these traits of dairy farming system, individual farms within dairy system, animal factors, and milk composition. A total of 1,211 model cheeses were produced in the laboratory using individual 1.5-L milk samples from Brown Swiss cows reared on 83 farms located in Trento Province. During ripening $\left(60 \mathrm{~d}\right.$; temperature $15^{\circ} \mathrm{C}$, relative humidity $85 \%$ ), the weight of all model cheeses was measured, and cheese yield (cheese weight/processed milk weight, \%CY) was calculated at 7 intervals from cheese-making $(0,1,7,14,28,42$, and 60 d). Using these measures, a 2-compartment first-order kinetic model (3-parameter equation) was developed for modeling $\% \mathrm{CY}$ during the ripening period, as follows: $\% \mathrm{CY}_{t}=\% \mathrm{CY}_{\mathrm{f}}+\left(\% \mathrm{CY}_{\mathrm{i}}-\% \mathrm{CY}_{\mathrm{f}}\right) \times e^{-\mathrm{k}_{\mathrm{CY}} \times \mathrm{t}}$, where $\% \mathrm{CY}_{\mathrm{t}}$ is the $\% \mathrm{CY}$ at ripening time $\mathrm{t} ; \% \mathrm{CY}_{\mathrm{i}}$ and $\% \mathrm{CY}_{\mathrm{f}}$ are the modeled $\% \mathrm{CY}$ traits at time $0 \mathrm{~d}\left(\% \mathrm{CY}_{\mathrm{i}}=\right.$ initial $\% \mathrm{CY}$ ) and at the end of a ripening period sufficient to reach a constant wheel weight $\left(\% \mathrm{CY}_{\mathrm{f}}=\right.$ final $\% \mathrm{CY}$ after $60 \mathrm{~d}$ ripening in the case of small model cheeses); $\mathrm{k}_{\mathrm{CY}}$ is the instant rate constant for cheese weight loss (\%/d). Cheese weight and protein and fat losses were calculated as the \% difference between the model cheeses at 0 and after $60 \mathrm{~d}$ of ripening. The variation in cheese $\mathrm{pH}$ was calculated as the $\%$ difference between $\mathrm{pH}$ at 0 and after $60 \mathrm{~d}$. Dairy system, individual herd within dairy system, and the cow's parity and lactation
\end{abstract}

Received October 31, 2019.

Accepted March 28, 2020.

*Corresponding author: andrea.summer@unipr.it stage (tested with a linear mixed model) strongly affected almost all the traits collected during model cheese ripening. Milk fat, protein, lactose, $\mathrm{pH}$, and somatic cell score also greatly affected almost all the traits, although $\mathrm{k}_{\mathrm{CY}}$ was affected only by milk protein. After including milk composition in the linear mixed model, the importance of all the herd and animal sources of variation was greatly reduced for all traits. The proposed model and novel traits could be tested, first, with the aim of establishing new monitoring procedures enabling the dairy industry to improve milk quality-based payment systems at the herd level and, second, with a view to exploring possible genetic improvements to dairy cow populations.

Key words: cheese maturation, cheese yield, novel phenotypes, cheese quality, ripening prediction

\section{INTRODUCTION}

The characteristics of ripened cheese are influenced by curd yield, the milk components and microorganisms retained at the beginning of ripening (Green and Grandison, 1993), and ripening conditions (water activity, salt concentration and diffusion, environmental temperature, and relative humidity). One of the most important phenomena during ripening is the evaporation of cheese moisture from the crust and its migration from the inner part of the wheel toward the surface. In the meantime, several biochemical pathways driving cheese ripening take place in the cheese, such as the metabolism of lactose, citrate, and lactate; lipolysis; fatty acids metabolism; proteolysis; and amino acid catabolism (Fox et al., 2017). The principal agents of these biochemical transformations are the native enzymes of milk, the enzymes of the native and added microorganisms, and those of the coagulant. All these concurrent processes are time-dependent and largely influence the cheese weight and nutrient losses (\% CL) during ripening and the final cheese yield $(\mathbf{\%} \mathbf{C Y})$, which depends mainly on the length of the ripening period (Walstra et al., 2006; Law and Tamine, 2010). The ripening 
period is highly variable among cheeses produced by enzymatic coagulation and can range from about $2 \mathrm{wk}$ to more than 2 yr (McSweeney, 2017).

Although ripening has been extensively studied (Fox et al., 2017; McSweeney, 2017), and different models for monitoring the biochemical reactions involved have been proposed (Riahi et al., 2007; Gaucel et al., 2012), dairy factories do not have total control over this process. In factories with a low level of automation, in particular, cheese-makers assess the progress of ripening by taking a few measurements on a small number of wheels randomly selected from all those produced in a given cheese-making session, or from wheels produced in different batches or sessions (Martín-del-Campo et al., 2007). Of all the traits that should be controlled during ripening, $\% \mathrm{CY}$ is conceptually simple to assess. However, the investment required for continuous monitoring of \% CY during ripening is too high in terms of time, labor, and number of operators involved to be justified. Almost all dairy industries develop their own models for predicting and monitoring fresh \% CY, such as the quantity of cheese obtained at the end of cheese-making as a percentage of the milk processed, which are based on milk characteristics, the cheese-making procedure, and the plants and operators involved (Formaggioni et al., 2015). However, they have seldom developed affordable models for predicting the evolution of $\% \mathrm{CY}$ during ripening, which are able to weigh the wheels and quantify nutrient losses to program and optimize the characteristics of the final product. Moreover, \%CL during ripening and final \%CY are particularly important for those dairy enterprises manufacturing protected designation of origin products, which include dimension and weight among their conformity criteria, and whose market is often restricted by voluntary quota systems (Barjolle et al., 2005). Some basic knowledge and information are required to develop models for predicting $\% \mathrm{CY}$ according to length of ripening period. The first is an understanding of the time-dependent kinetics of wheel weight during ripening. In addition, there is a need for knowledge of the effect on the kinetics of factors related to dairy farm characteristics (above all, the dairy system and the influence of individual farms within dairy system), individual animal characteristics (parity, stage of lactation, genetics), and the composition of the milk processed.

Laboratory cheese-making procedures allow researchers to use small quantities of milk in the vat to process large numbers of milk samples, and to have a greater amount of control over the experimental conditions across the entire process from milk collection to the end of model cheese ripening. This approach is particularly interesting because it allows us (a) to produce a high number of small model cheeses in a relatively short time, with high variability in terms of quality when analyzed at the individual animal level, (b) to overcome logistical and economic limitations related to cheese monitoring during ripening, and (c) to generate useful knowledge that can be applied in the dairy industry. Results obtained with model cheeses are not, of course, directly applicable to commercial situations, but they do allow us to test modeling procedures and acquire useful knowledge that could help dairy industries develop specific models. They could also be used for testing the influence of genetics on new cheese ripening phenotypes, with a view to future genetic improvement of dairy populations. Against this background, the aims of the present study were (i) to propose and test a 2-compartment 3-parameter first-order kinetic model for cheese weight loss over the ripening period; (ii) to collect new informative phenotypes related to the evolution of cheese ripening; (iii) to assess the effects of dairy farming systems, individual farms within dairy system, and animal factors (such as parity and lactation stage) on the kinetics of weight loss in ripening cheeses; and (iv) to assess the relative importance of milk components on measured and modeled \%CY and on \%CL traits during ripening.

\section{MATERIALS AND METHODS}

\section{Milk Sampling and Analyses}

Herd selection and milk sampling for the present study, part of the "Cowability-Cowplus" project, are described in detail in Bittante et al. (2015). Briefly, individual milk samples were taken from 1,211 cows reared in 83 herds in Trento Province, Italy. With few exceptions, 15 cows from each herd were selected to represent different parities, lactation stages, and milk yield, and were sampled once during the evening milking. The herds were chosen from 610 farms selected as representative of the different environments in the province, and were classified into 4 different dairy farming systems (3 modern and 1 traditional) according to farm size, production level, management, and feeding system (Schiavon et al., 2019). Details of the environmental contexts and dairy farming systems of the 83 farms selected are reported in Bittante et al. (2015). In brief, the first dairy system consisted of very traditional farms with tied cows fed mainly on meadow hay and some compound feed (with or without automatic stall feeders). In the other 3 (modern) dairy systems, the cows were loose-housed indoors and milked in parlors, but the farms differed in their feedstuff distribution systems. In the second dairy system (no TMR), the feeds (mainly meadow hay and compound feed) were distributed to the manger separately; the other 2 used 
TMR, one with silages, the other without. The herds were sampled once during a calendar year, taking into account their distribution among the different dairy systems. Individual gross milk composition (fat, protein, and lactose) was analyzed within $20 \mathrm{~h}$ of milking, using a MilkoScan FT6000 (Foss, Hillerød, Denmark) calibrated according to the following reference methods: fat (ISO, 2010; ISO1211|IDF 1; gravimetric method, Rose-Gottlieb); protein (ISO, 2014; ISO 8968-1|IDF 20-1; titrimetric method, Kjeldahl); lactose (ISO, 2002; ISO 5765-1|IDF 79-1; enzymatic method). Milk pH, adjusted for sample temperature, was measured with a Crison Basic 25 electrode (Crison Instruments SA, Barcelona, Spain). Somatic cell scores (Ali and Shook, 1980) were calculated from SCC measured with a Fossomatic FC counter (Foss). The dairy cows sampled $($ mean $\pm \mathrm{SD}): \mathrm{DIM}=180 \pm 110$; number of parities $=$ $2.54 \pm 1.40)$ produced an average of $24.22 \pm 7.81 \mathrm{~kg} / \mathrm{d}$ of milk, containing $4.33 \% \pm 0.76$ fat, $3.74 \% \pm 0.41$ protein, and $4.77 \% \pm 0.23$ lactose, and had an average SCS of $2.98 \pm 1.84$ (data not shown).

\section{Model Cheeses}

Individual milk samples $(1,500 \mathrm{~mL}$ each $)$ were processed according to the cheese-making method described in Cipolat-Gotet et al. (2013), mimicking common cheese types often called Latteria. Briefly, 1,500 $\mathrm{mL}$ of milk was heated to $35^{\circ} \mathrm{C}$ and supplemented with thermophilic starter culture. The starter consisted of an industrial freeze-dried formulation of thermophilic lactic bacteria (Delvo-Tec TS-10A DSL; DSM Food Specialties, Delft, the Netherlands). Calf rennet (Hansen standard 160 with $80 \pm 5 \%$ chymosin and $20 \pm$ 5\% pepsin; 160 international milk clotting units/mL; Pacovis Amrein AG, Bern, Switzerland) was diluted 20:1 with distilled water, and $9.6 \mathrm{~mL}$ of rennet solution was added to each vat. Ten minutes after the operator observed milk gelation, the curd was cut, using a vertical cross cut centered on the vertical axis of the vat. Five minutes after the first cut, the curd was reduced into cubes of about $1 \mathrm{~cm}^{3}$. After $5 \mathrm{~min}$, the curd was separated from the whey and suspended on a cheese mold for $30 \mathrm{~min}$; the mold was suspended over the whey-containing vat, and the curd was turned every $2 \mathrm{~min}$ to facilitate draining. The curd was then pressed for $60 \mathrm{~min}$ at $250 \mathrm{kPa}$ with turning every $20 \mathrm{~min}$. The whey collected from each vat was also weighed, sampled, and analyzed. At the end of cheesemaking, whey composition (fat, protein, and lactose) was determined with an FT2 (Foss). Curd components (fat and protein) were measured as the difference in composition between the milk processed and the whey. At the end of the cheese-making process and after the brining phase (60 min in brine with a saturated solution of $20 \% \mathrm{NaCl}$ ), each cheese wheel was weighed, and $\mathrm{pH}$ was measured (3 measurements per sample, averaged before data analysis) with a Crison Basic 20 electrode (Crison Instruments SA). The cheeses were then ripened at $15^{\circ} \mathrm{C}$ and $85 \%$ relative humidity for the first month, and at $12^{\circ} \mathrm{C}$ and the same relative humidity for the second month. During the 2-mo ripening period, each cheese was weighed and mold removed from the rind with a saline solution at 7, 14, 28, and 42 $\mathrm{d}$ from processing. At the end of ripening, each wheel was weighed, and after removing the rind, the chemical components (fat, protein, and salt) were measured with a FoodScan (Foss). Cheese acidity was measured 3 times per sample and averaged before data analysis (Crison Basic 25 with a 5054 TC combined electrode; Crison Instruments SA).

With these procedures, we were able to obtain the following pool of traits related to \%CY and \%CL during ripening of the model cheeses: $\% \mathrm{CY}_{0 \mathrm{~d}},{ }^{2} \mathrm{CY}_{1 \mathrm{~d}}$, $\% \mathrm{CY}_{7 \mathrm{~d}}, \% \mathrm{CY}_{14 \mathrm{~d},} \% \mathrm{CY}_{28 \mathrm{~d}}, \% \mathrm{CY}_{42 \mathrm{~d}}$, and $\% \mathrm{CY}_{60 \mathrm{~d}}$, being the ratio of the weight $(\mathrm{g})$ of the cheese at $0 \mathrm{~d}$ (after brining), and after $1,7,14,28,42$, and $60 \mathrm{~d}$ of ripening to the weight of the processed milk $(\mathrm{g})$, respectively; cheese weight, protein, and fat losses $\left(\mathbf{\%} \mathbf{C L}_{\text {WEIGHT }}\right.$, \% $\mathbf{C L}_{\text {PROTEIN }}, \mathbf{\%}_{\mathbf{C L}}$ FAT), being the percentage difference in weight, fat, and protein, respectively, between the model cheeses at $\mathrm{d} 0$ and after $60 \mathrm{~d}$ of ripening. Variations in $\mathrm{pH}(\Delta \mathrm{pH})$ were measured as the percentage difference between the model cheeses at d 0 and after $60 \mathrm{~d}$ of ripening.

\section{Cheese Yield Modeling Over the Ripening Period}

The $\% \mathrm{CY}$ of model cheeses made from individual milk samples as a function of the length of ripening period was modeled with the following objectives: (a) to use a few simple measurements taken over the ripening period; (b) to have a goodness of fit, even in the presence of high variability in milk composition; and (c) to extract a few comprehensive, technologically useful equation parameters. The model rested on the assumption that the cheese can be theoretically divided into 2 compartments (Figure 1): (a) the disappearing compartment (mainly water but also fat, protein, and lactose), which is destined to be lost during ripening; and (b) the remaining compartment (mainly fat, protein, minerals, and some water), which is destined to remain at the end of a theoretically infinite ripening period, and which could be identified as the minimum final cheese yield $\left(\mathbf{\%} \mathbf{C} \mathbf{Y}_{\mathrm{f}}\right)$ obtainable from a cheese wheel after this period. An approximate $\% \mathrm{CY}_{\mathrm{f}}$ value may be obtained when the weight of the wheel is tending to stabilize $\left(\mathrm{CW}_{\mathrm{f}}\right)$, because (i) all the moisture contained 


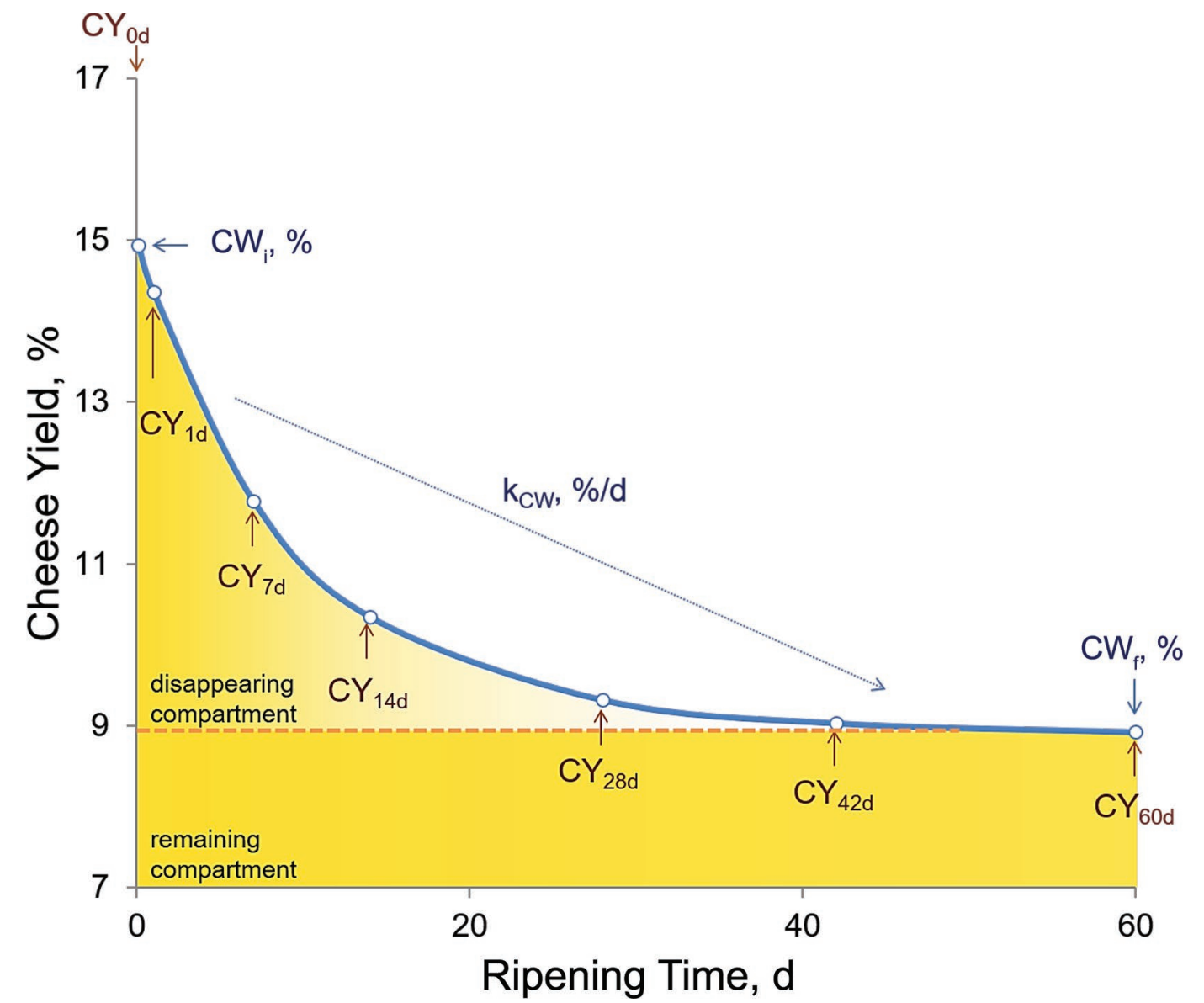

Figure 1. Pattern of $\mathrm{CY}_{\mathrm{t}}$ (cheese yield at time t; average of 1,198 individual model cheeses) predicted by a 2-compartment (the disappearing compartment, which is destined to be lost during ripening, and the remaining compartment, which is destined to remain at the end of a theoretically infinite ripening period) 3-parameter first-order kinetic model for cheese weight loss over the ripening period. The font color of the observed \% CY traits is brown, whereas that of the predicted traits by the proposed model is blue. $\mathrm{CW}_{\mathrm{i}}=$ initial cheese weight; $\mathrm{CW}_{\mathrm{f}}=$ final cheese weight; $\mathrm{k}_{\mathrm{CY}}=$ instant constant rate.

in the cheese is in hygroscopic equilibrium with the air (depending on air temperature, humidity, and movement); (ii) bound water molecules in the cheese interact through secondary bonds with charged molecules of the cheese (which increase during ripening due to lipolysis and proteolysis); and (iii) enzymatic and microbiological activity is almost null. The $\% \mathrm{CY}_{\mathrm{f}}$ can be calculated as the ratio between $\mathrm{CW}_{\mathrm{f}}$ and the weight of the milk processed (MW), as follows:

$$
\% \mathrm{CY}_{\mathrm{f}}=\mathrm{CW}_{\mathrm{f}} / \mathrm{MW}
$$

The compartment destined to disappear during ripening can be quantified as the difference between the initial $\left(\mathbf{\%} \mathbf{C Y} \mathbf{Y}_{\mathbf{i}}\right)$ and final $\left(\% \mathrm{CY}_{\mathrm{f}}\right)$ cheese yields. The disappearance of this compartment was assumed to follow a first-degree kinetics; that is, the loss would be a constant proportion of the weight of the compartment during ripening. The resulting prediction of $\% \mathrm{CY}$ at time $\mathrm{t}\left(\mathbf{\%} \mathbf{C Y} \mathbf{Y}_{\mathbf{t}}\right)$ is therefore the sum of the remaining compartment $\left(\% \mathrm{CY}_{\mathrm{f}}\right)$ and the proportion of the disappearing compartment dependent on time $t$ :

$$
\% \mathrm{CY}_{\mathrm{t}}=\% \mathrm{CY}_{\mathrm{f}}+\left(\% \mathrm{CY}_{i}-\% \mathrm{CY}_{\mathrm{f}}\right) \times e^{-\mathrm{k}_{\mathrm{CY}} \times \mathrm{t}},
$$

where $\% \mathrm{CY}_{\mathrm{t}}$ is the $\% \mathrm{CY}$ at time $\mathrm{t}$ (expressed as $\%$ of the weight of the milk processed); $\% \mathrm{CY}_{\mathrm{i}}$ and $\% \mathrm{CY}_{\mathrm{f}}$ are the modeled \% CY traits at the beginning $(0 \mathrm{~d})$ and end $(60 \mathrm{~d})$ of ripening, respectively; $\mathbf{k}_{\mathrm{CY}}$ is the instant rate constant for cheese weight loss $(\% / d)$, and $t$ is the number of days of ripening from cheese-making. The pattern described by the model is represented in Figure 1 together with the average $\mathrm{CY}_{\mathrm{t}}$ values measured at the 7 ripening intervals in all 1,211 model cheeses.

The $7 \% \mathrm{CY}_{\mathrm{t}}$ observations (from 0 to $60 \mathrm{~d}$ ) for each model cheese were fitted with curvilinear regressions according to the proposed model and using the SAS 
nonlinear procedure (PROC NLIN; SAS Institute Inc., Cary, NC). The parameters of the equation of each individual model cheese wheel were estimated using the Marquardt iterative method (350 iterations and a $10^{-5}$ level of convergence). We assessed the fit of the proposed model using the convergence of individual equations, the coefficient of determination, and the residual standard deviation (SD). We also conducted separate linear regressions between the measured and estimated values of \%CY traits for each ripening interval $(0,1,7$, $14,28,42$, and $60 \mathrm{~d})$.

\section{Statistical Analysis}

Experimental data were examined using the MIXED procedure of SAS, according to the following linear model (basic model):

$$
\begin{gathered}
\mathrm{Y}_{\mathrm{ijklm}}=\mu+\text { dairy-system }_{\mathrm{i}}+\text { herd }_{\mathrm{j}}\left(\text { dairy-system }_{\mathrm{i}}\right. \\
+\mathrm{DIM}_{\mathrm{k}}+\text { parity }_{\mathrm{l}}+\mathrm{e}_{\mathrm{ijklm}},
\end{gathered}
$$

where $\mathrm{Y}_{\mathrm{ijklm}}$ is the observed trait (observed $\% \mathrm{CY}, \% \mathrm{CY}$ equation parameters, \%CL, and $\Delta \mathrm{pH}) ; \mu$ is the overall mean; dairy-system ${ }_{i}$ is the fixed effect of the ith dairy system ( $\mathrm{i}=1$ to 4$) ; \operatorname{herd}_{\mathrm{j}}(\text { dairy-system })_{\mathrm{i}}$ is the random effect of the jth herd ( $\mathrm{j}=1$ to 83 ) within the ith dairy system; $\mathrm{DIM}_{\mathrm{k}}$ (where DIM is the interval from calving to milk sampling) is the kth 60 -d class of DIM $(\mathrm{k}=1$ to 6; class 1: $\leq 60 \mathrm{~d}$; class 2: 61 to $120 \mathrm{~d}$; class 3: 121 to $180 \mathrm{~d}$; class 4: 181 to $240 \mathrm{~d}$; class 5: 241 to $300 \mathrm{~d}$; class 6: $>300 \mathrm{~d}$ ); parity is the fixed effect of the lth parity (1 $=1$ to $\geq 5$ lactations); and $\mathrm{e}_{\mathrm{ijklm}}$ is the residual random error term $\sim N\left(0, \sigma^{2}\right)$. Significance of dairy system was tested on the error line of herd within dairy system, and DIM class and parity were tested on the error line of animal within DIM class and parity.

To test the variability in ripening traits due to the composition of the milk used to make the cheeses, a further model (extended model) was obtained from the basic model with the additional inclusion of fixed effects of milk protein, fat, lactose, $\mathrm{pH}$, and SCS. The 7 classes of these 5 milk quality traits were determined on the basis of the distribution of the variables: each class explained $0.5 \mathrm{SD}$ of the variable, the fourth being centered on the mean value, and the first and seventh represented the tails of the distribution.

\section{RESULTS AND DISCUSSION}

\section{Cheese Quality During Ripening}

Table 1 shows the descriptive statistics for the chemical composition of the fresh and ripened model cheeses, weight and nutrient losses, and $\mathrm{pH}$ variation after $60 \mathrm{~d}$ of ripening. Although milk quality is normally standardized in the dairy industry, and cheese-making stages are adjusted to produce cheeses with unvarying characteristics across different processing sessions, we decided to process the individual milk samples without any pre-treatment (i.e., milk fat:protein ratio and $\mathrm{pH}$ standardization), to fully capture the variability related to the effects of farm, animal, and milk quality. Moreover, manufacturing a large number of model cheeses from individual milk samples with high variability in composition has the potential to provide new knowledge that may be particularly useful for traditional production methods using non-standardized raw milk, as in the case of many protected designation of origin cheeses (Gobbetti et al., 2018). Furthermore, using the procedural protocol described in Cipolat-Gotet et al. (2013) allowed us to exert rigorous control over all the phases of milk collection, cheese-making, and ripening, and to take all precautions to ensure maximum reproducibility from one cheese-making session to another.

As expected, ripened model cheeses varied greatly in terms of composition (Table 1), more than cheeses produced from bulk milk normally do (Cichoscki et al., 2002; Malacarne et al., 2009), mainly because of the variability in the composition of the milk processed. Using these data, Bittante et al. (2013) found that the variability in fresh \%CY was explained partly by animal (genetic and non-genetic effects) and partly by farm.

In the present study, $\% \mathrm{CY}$ at the extraction of wheels from brining $(0 \mathrm{~d})$ was about $15 \%$ (Table 2$)$, and $\% \mathrm{CL}_{\text {WEIGHT }}$ stood at $41 \%$ after 2 mo of ripening (Table 1). During this interval, the \%CY of the ripened model cheeses decreased to $8.71 \%$, and a reduction in variability also occurred at each subsequent \%CY measurement. From d 0 to the end of ripening, the SD of \%CY also decreased by about $40 \%$ (Table 2). This means that no change in the variation in $\% \mathrm{CY}$ occurred during ripening, when expressed as a coefficient of variation ( $\sim 12 \%$ of the mean). Because model cheeses are very small (and also have a large surface/volume ratio), moisture is lost more quickly, and after $60 \mathrm{~d}$ of ripening the losses in cheese weight and the \% CY were similar to those observed in much heavier wheels of cheeses classified as very hard (Davis, 1965). The model cheeses were by then close to weight stability. Assessment of sensory traits and texture on the same model cheeses (Cipolat-Gotet et al., 2018), and analysis of the volatile organic compound content to characterize their flavor (Bergamaschi et al., 2015a,b) confirmed their similarity to very hard cheeses. Nutrient losses in the different model cheeses after 2 mo of ripening ranged from 0 to about $9 \%$ for protein $\left(\% \mathrm{CL}_{\text {PROTEIN }}\right)$ and to about $6 \%$ for fat $\left(\% \mathrm{CL}_{\mathrm{FAT}}\right)$. The average $\mathrm{pH}$ of 
Table 1. Descriptive statistics of chemical composition of fresh and ripened model cheeses, of losses of weight and nutrients of cheese $(\% \mathrm{CL})$, and of $\mathrm{pH}$ variation $(\Delta \mathrm{pH}, \%)$ of model cheeses after $60 \mathrm{~d}$ of ripening ${ }^{1}$

\begin{tabular}{|c|c|c|c|c|c|}
\hline \multirow[b]{2}{*}{ Trait } & \multicolumn{5}{|c|}{ Descriptive statistics } \\
\hline & $\mathrm{N}$ & Mean & $\mathrm{SD}$ & P5 & P95 \\
\hline \multicolumn{6}{|l|}{ Fresh cheese } \\
\hline Protein, \% & 1,203 & 19.5 & 1.57 & 17.1 & 22.3 \\
\hline Fat, $\%$ & 1,195 & 26.0 & 4.01 & 20.1 & 32.7 \\
\hline Fat:protein & 1,172 & 1.33 & 0.23 & 0.99 & 1.76 \\
\hline $\mathrm{pH}$ & 923 & 6.23 & 0.18 & 5.87 & 6.46 \\
\hline \multicolumn{6}{|c|}{ Ripened cheese } \\
\hline Protein, \% & 1,068 & 26.8 & 4.01 & 20.0 & 32.9 \\
\hline Fat, $\%$ & 1,060 & 38.1 & 4.04 & 31.7 & 45.2 \\
\hline Salt, \% & 1,063 & 2.04 & 0.06 & 1.90 & 2.12 \\
\hline $\mathrm{pH}$ & 1,204 & 5.17 & 0.17 & 4.87 & 5.45 \\
\hline \multicolumn{6}{|c|}{ Cheese losses, \% } \\
\hline$\% \mathrm{CL}_{\text {WEIGHT }}$ & 1,141 & 40.89 & 5.35 & 15.58 & 54.31 \\
\hline$\% \mathrm{CL}_{\text {PROTEIN }}$ & 1,036 & 3.37 & 1.88 & 0.01 & 8.79 \\
\hline$\% \mathrm{CL}_{\mathrm{FAT}}$ & 999 & 2.33 & 1.09 & 0.05 & 5.91 \\
\hline$\Delta \mathrm{pH}, \%$ & 909 & 17.15 & 2.58 & 9.53 & 24.64 \\
\hline
\end{tabular}

${ }^{1} \mathrm{P} 5=5$ th percentile; $\mathrm{P} 95=95$ th percentile. $\% \mathrm{CL}_{\text {WEIGHT }}, \% \mathrm{CL}_{\mathrm{PROTEIN}}, \% \mathrm{CL}_{\mathrm{FAT}}=$ weight, protein, and fat losses (as \% of the amount after wheel pressing) of model cheeses after $60 \mathrm{~d}$ of ripening. $\Delta \mathrm{pH}=\mathrm{pH}$ variations (as $\%$ of the value at $0 \mathrm{~d}$ ) of model cheeses after $60 \mathrm{~d}$ of ripening.

the matured model cheeses was also comparable to that of commercial hard cheeses ripened for more than 6 mo (McSweeney, 2017).

\section{Modeling the Evolution of Cheese Yield During Ripening}

Modeling cheese weight losses is the first step in monitoring \%CY during ripening. Given the high importance of the final \% CY and cheese quality, several authors have proposed different ways of modeling the ripening processes of a wide variety of cheeses. In most cases, the use of multivariate statistical analyses of detailed cheese quality traits has allowed the development of useful methods for predicting the indices of cheese maturity. Among these studies, peak data from reversed-phase (RP)-HPLC has been used to assign the category of maturity to Cheddar cheese (Pham and Nakai, 1984; O'Shea et al., 1996). Santa-María et al. (1986) used various nitrogen fractions to make the same predictions for Manchego cheese, whereas Fallico et al. (2004) found peptide profiles to be the most

Table 2. Descriptive statistics of measured and predicted cheese yield traits (\%CY, weight of cheese expressed as percentage of the weight of processed milk), of $\% \mathrm{CY}_{\mathrm{t}}$ equation parameters (cheese yield according to time of ripening), and of linear regressions between measured and predicted $\% \mathrm{CY}^{1}$

\begin{tabular}{|c|c|c|c|c|c|c|c|c|}
\hline Item & \multicolumn{4}{|c|}{ Descriptive statistics } & \multicolumn{4}{|c|}{ Linear regressions } \\
\hline \multicolumn{9}{|c|}{ Cheese yield, \% } \\
\hline$\% \mathrm{CY}_{1 \mathrm{~d}}$ & 1,206 & $14.20 \pm 1.84$ & 1,193 & $14.32 \pm 1.81$ & $-0.09^{*}$ & 0.998 & 0.17 & 0.991 \\
\hline$\% \mathrm{CY}_{7 \mathrm{~d}}$ & 1,203 & $11.72 \pm 1.78$ & 1,194 & $11.76 \pm 1.68$ & $-0.51^{* * *}$ & $1.042^{* * *}$ & 0.26 & 0.978 \\
\hline$\% \mathrm{CY}_{14 \mathrm{~d}}$ & 1,205 & $10.35 \pm 1.45$ & 1,194 & $10.32 \pm 1.49$ & $0.57^{* * *}$ & $0.947^{* * *}$ & 0.24 & 0.972 \\
\hline \multicolumn{9}{|c|}{$\% \mathrm{CY}_{\mathrm{t}}$ equation parameters } \\
\hline$\% \mathrm{CY}_{\mathrm{i}}, \%$ & - & - & 1,204 & $14.95 \pm 1.87$ & - & - & - & - \\
\hline$\% \mathrm{CY}_{\mathrm{f}}, \%$ & - & - & 1,205 & $8.85 \pm 1.15$ & - & - & - & - \\
\hline $\mathrm{k}_{\mathrm{CY}}, \% / \mathrm{d}$ & - & - & 1,203 & $11.37 \pm 3.79$ & - & - & - & - \\
\hline RMSEP & - & - & 1,211 & $0.21 \pm 0.11$ & & & & \\
\hline
\end{tabular}

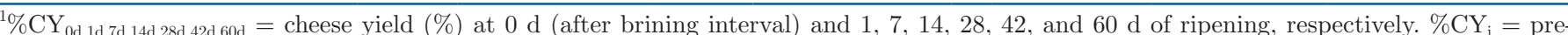
dicted cheese yield at $0 \mathrm{~d} ; \% \mathrm{CY}_{\mathrm{f}}=$ predicted cheese yield at $60 \mathrm{~d} ; \mathrm{k}_{\mathrm{CY}}=$ cheese yield losses instant rate constant $(\% / \mathrm{d})$. a $=$ intercept $(P$-value for testing if the intercept is different from 0.00$) ; \mathrm{b}=$ slope ( $P$-value for testing if the slope is different from 1.00$)$; RMSE $=$ root means square error; RMSEP $=$ root means square error of the prediction

${ }^{*} P<0.05 ;{ }^{* *} P<0.01 ;{ }^{* * *} P<0.001$. 
useful sources of information for determining the age of Ragusano cheese. However, although these studies produced results that were useful for differentiating the age categories of cheese, none provided any information on \%CY during ripening. Other authors have developed models for predicting weight losses and mass transfer during ripening, using the information from traits involved in the most important physical and biochemical processes. For example, Riahi et al. (2007) proposed a model for predicting the total and DM weights of smear soft cheeses during ripening using cheese water activity and $\mathrm{CO}_{2}$ release, and Hélias et al. (2007) developed a mechanistic model for predicting mass transfer in Camembert cheese by recording online measurements of cheese respiratory activity. The results of both these studies have been tested using a reaction engineering approach, with good results (Putranto et al., 2018). Gaucel et al. (2012) proposed a generalized model to assess cheese mass loss during ripening of Camembert and Saint-Nectaire cheeses based on the analysis of water activity on the cheese rind and measurements of relative humidity during ripening. Corrieu et al. (2018) found that the mass loss in Raclette cheese during ripening was related mainly to local air velocity. However, although the models proposed in the aforementioned studies exhibited goodness of fit and produced useful predictable traits, they cannot be easily applied in the dairy industry, for 2 reasons: (i) the cheese biochemical and physical explanatory variables used to create the predictive models were obtained using time-consuming, high-cost analytical methods; (ii) the predictive models indirectly measured phenomena occurring during the ripening of specific cheeses or specific categories of cheese.

Unlike the aforementioned studies, our goal was to model the cheese ripening process using traits that can be measured rapidly and at low cost, and that may easily serve as cheese-making tools in the dairy industry. To fulfil this objective, we used only milk and cheese weights to model \%CY. By modeling $7 \% \mathrm{CY}_{\mathrm{t}}$ observations of each model cheese, we were able to produce equations for all the individual model cheeses that satisfied all the convergence criteria. These equations had a very good fit and a mean coefficient of determination of 0.991. This confirms the validity of the assumption that cheese is composed of 2 compartments, the first destined to be lost during ripening, the second destined to remain at the end of a theoretically infinite ripening period, and that the disappearance of the former compartment follows first-degree kinetics (provided that temperature, humidity, and air movement remain constant during ripening).

Compared with the variability in the $\% \mathrm{CY}$ of the model cheeses during ripening, the average residual SD of the model was very low $(0.21 \% \pm 0.11)$. Descriptive statistics of the measured and estimated values of $\% \mathrm{CY}$, together with the $\% \mathrm{CY}_{\mathrm{t}}$ equation parameters, are given in Table 2. It is worth noting that, even considering each specific ripening interval separately, the average $\% \mathrm{CY}$ values and the SD predicted by the model were almost identical to those of the measured traits. The goodness of the predictions is also confirmed by the correlation coefficient between the predicted and measured \%CY, which was always $>0.97$, and the root mean square error, which was $<0.3$ percentage points (Table 2). Moreover, although the intercept of the linear regression equations differed significantly from 0.00 , it was close to $0.00(-0.51$ to $+0.57 \%)$, and the corresponding regression coefficients were always very close to the expected value of 1.00 (0.947 to 1.042; Table 2).

It is difficult to compare our results with those from previous studies because of the differences in the traits used to estimate cheese weight or mass loss, the statistical approaches, the traits to be predicted, the category or type of cheese, and the length of ripening. Despite the great variability in individual milk samples and the high mean $\% \mathrm{CL}_{\text {WEIGHT }}$ values (Table 1 ), the error of the predicted values of individual model cheeses $(5.4 \%$ \pm 3.4 ) in our study was much lower than that reported by Gaucel et al. (2012) for total mass transfer at the end of ripening of Saint-Nectaire $(13.1 \% \pm 12.6)$ and Camembert $(14.2 \% \pm 8.6)$ cheeses.

With regard to the $\% \mathrm{CY}_{\mathrm{t}}$ equation parameters, despite the cheese-making process and the ripening conditions being highly controlled across individual samples and sessions, the model cheeses varied greatly in terms of their patterns of $\% \mathrm{CY}_{t}$, although the values at the beginning and end of ripening were less variable (Table 2 ). Compared with the other 2 parameters of the $\% \mathrm{CY}_{\mathrm{t}}$ model $\left(\% \mathrm{CY}_{\mathrm{i}}: \mathrm{CV}=12.5 \% ; \% \mathrm{CY}_{\mathrm{f}}: \mathrm{CV}=13.0 \%\right), \mathrm{k}_{\mathrm{CY}}$, which measures the relative rapidity of cheese weight losses, was highly variable $(\mathrm{CV}=34 \%)$. As expected, the predicted $\% \mathrm{CY}_{\mathrm{i}}$ and $\% \mathrm{CY}_{\mathrm{f}}$ parameters were very similar to the measured $\% \mathrm{CY}_{0 \mathrm{~d}}$ and $\% \mathrm{CY}_{60 \mathrm{~d}}$ traits, in terms of both mean and variability.

\section{Effects of Dairy Farming System and Individual Farm on the Evolution of \% CY During Ripening}

The scientific literature contains many studies on the effects of various factors on the $\% \mathrm{CY}$ at specific ripening times. However, no reports exist on the effects of environmental (dairy system and individual herd within dairy system) and individual animal factors on the phenotypes related to the evolution of cheese yield during ripening, so we cannot directly compare our findings with any previous studies. The results we obtained regarding the effects of dairy farming system, 
Table 3. Results from base ANOVA model ( $F$-value and significance) of cheese yield (\%CY, weight of cheese expressed as percentage of the weight of processed milk), of $\% \mathrm{CY}_{\mathrm{t}}$ modeling equation parameters (cheese yield according to time of ripening), of losses of weight and nutrients (\% CL), and of $\mathrm{pH}$ variation $(\Delta \mathrm{pH}, \%)$ of model cheeses after $60 \mathrm{~d}$ of ripening, based on dairy system, herd within dairy system, DIM, and parity of cows

\begin{tabular}{|c|c|c|c|c|c|}
\hline \multirow[b]{2}{*}{ Trait $^{1}$} & \multirow{2}{*}{$\begin{array}{l}\text { Dairy } \\
\text { system }\end{array}$} & \multirow[b]{2}{*}{ DIM } & \multirow[b]{2}{*}{ Parity } & \multicolumn{2}{|c|}{$\mathrm{RMS}^{2}$} \\
\hline & & & & Herd/date & Residual \\
\hline \multicolumn{6}{|l|}{ \%Cheese yield } \\
\hline$\% \mathrm{CY}_{0 \mathrm{~d}}$ & $4.2^{* *}$ & $56.3^{* * *}$ & $6.1^{* * *}$ & 0.81 & 1.41 \\
\hline$\% \mathrm{CY}_{1 \mathrm{~d}}$ & $3.2^{*}$ & $57.1 * * *$ & $6.9^{* * *}$ & 0.85 & 1.37 \\
\hline$\% \mathrm{CY}_{7 \mathrm{~d}}$ & 1.9 & $51.5^{* * *}$ & $6.0^{* * *}$ & 0.94 & 1.29 \\
\hline$\% \mathrm{CY}_{14 \mathrm{~d}}$ & $2.9^{*}$ & $49.7 * * *$ & $8.9^{* * *}$ & 0.60 & 1.14 \\
\hline$\% \mathrm{CY}_{28 \mathrm{~d}}$ & $4.7^{* *}$ & $47.5^{* * *}$ & $9.8^{* * *}$ & 0.43 & 1.02 \\
\hline$\% \mathrm{CY}_{42 \mathrm{~d}}$ & $5.4^{* *}$ & $45.7^{* * *}$ & $8.1^{* * *}$ & 0.39 & 0.98 \\
\hline$\% \mathrm{CY}_{60 \mathrm{~d}}$ & $5.1^{* *}$ & $44.9^{* * *}$ & $7.5^{* * *}$ & 0.38 & 0.91 \\
\hline \multicolumn{6}{|c|}{$\% \mathrm{CY}_{+}$equation parameters } \\
\hline$\% \mathrm{CY}_{\mathrm{i}}, \%$ & $3.8^{*}$ & $56.0^{* * *}$ & $6.5^{* * *}$ & 0.85 & 1.40 \\
\hline$\% \mathrm{CY}_{\mathrm{f}}, \%$ & $5.6^{* *}$ & $41.7^{* * *}$ & $7.6^{* * *}$ & 0.39 & 0.94 \\
\hline $\mathrm{k}_{\mathrm{CY}}, \% / \mathrm{d}$ & 1.5 & $6.5^{* * *}$ & 0.5 & 2.54 & 2.71 \\
\hline \multicolumn{6}{|c|}{ Cheese losses, \% } \\
\hline \% CL & $4.6^{* *}$ & 1.2 & $3.6^{* *}$ & 6.44 & 2.42 \\
\hline$\% \mathrm{CL}_{\text {PROTEIN }}$ & 1.4 & $29.9^{* * *}$ & $3.9^{* *}$ & 0.97 & 1.49 \\
\hline$\% \mathrm{CL}_{\mathrm{FAT}}$ & 0.9 & 1.8 & $4.9^{* * *}$ & 0.53 & 0.94 \\
\hline$\Delta \mathrm{pH}, \%$ & 1.6 & $12.0^{* * *}$ & 1.6 & 1.68 & 1.92 \\
\hline
\end{tabular}

${ }_{1} \% \mathrm{CY}_{0 \mathrm{~d}, 1 \mathrm{~d}, 7 \mathrm{~d}, 14 \mathrm{~d}, 28 \mathrm{~d}, 42 \mathrm{~d}, 60 \mathrm{~d}}=$ cheese yield $(\%)$ at $0 \mathrm{~d}$ (after brining interval) and 1, 7, 14, 28, 42, and $60 \mathrm{~d}$ of ripening, respectively; $\% \mathrm{CY}_{\mathrm{i}}=$ predicted cheese yield at $0 \mathrm{~d} ; \% \mathrm{CY}_{\mathrm{f}}=$ predicted cheese yield at $60 \mathrm{~d} ; \mathrm{k}_{\mathrm{CY}}=$ cheese yield losses instant rate constant $(\% / \mathrm{d}) ; \% \mathrm{CL}_{\mathrm{WEIGHT}}, \% \mathrm{CL}_{\mathrm{PROTEIN}}, \% \mathrm{CL}_{\mathrm{FAT}},=$ losses of weight, protein, and fat of model cheeses after $60 \mathrm{~d}$ of ripening.

${ }^{2} \mathrm{RMS}=$ root mean square for herd and residual (random effects).

${ }^{*} P<0.05 ;{ }^{* *} P<0.01 ; * * * P<0.001$.

individual farms, and animal factors on the $\% \mathrm{CY}_{\mathrm{t}}$ equation parameters, cheese weight and nutrient losses, and variations in $\mathrm{pH}$ are given in Table 3. Two ANOVA (of the basic and extended models) allowed us to distinguish between the overall effect of environmental and individual factors on these traits (Table 3) and the indirect variability arising from differences due to the effects of milk composition (protein, fat, lactose, $\mathrm{pH}$, and SCS, included in the extended model, Table 4).

In the basic model, dairy farming system was significant at each ripening interval, with the sole exception of the \%CY measured at 1 wk from cheese-making (Table3). Dairy system also affected the initial and final $\% \mathrm{CY}$ predicted by the $\% \mathrm{CY}_{\mathrm{t}}$ model and the overall weight loss $\left(\% \mathrm{CL}_{\text {WEIGHT }}\right)$ but had a negligible effect on the instant rate constant of weight loss $\left(\mathrm{k}_{\mathrm{CY}}\right)$ and the overall loss of fat and protein (Table 3 ). The $\% \mathrm{CY}_{\mathrm{t}}$ model uses only 3 parameters, making it simple to produce patterns of $\% \mathrm{CY}_{\mathrm{t}}$ during ripening from the least squares means of effects (hence, corrected for possible nuisance factors), such as those presented in the figures. The modeling gave us a better understanding of the differences among cheeses due to dairy system. In Figure 2 (basic model) we can see that the curves of $\% \mathrm{CY}$ over time are almost parallel, and the dairy systems with the highest $\% \mathrm{CY}_{\mathrm{i}}$ (modern dairy systems using TMR with or without silages) are also those with the highest
$\% \mathrm{CY}_{\mathrm{f}}$. This means that the differences depend more on the quantity of nutrients retained in the curd during cheese-making than on the patterns of weight loss $\left(\mathrm{k}_{\mathrm{CY}}\right)$ of the wheels. This interpretation is fully confirmed by the results from the extended model: after taking into consideration the differences in milk composition, the differences among the dairy farming systems ceased to be significant (Table 4), and the curves of \%CY largely overlapped (Figure 2; extended model). Only in the extended model was \% $\mathrm{CL}_{\text {WEIGHT }}$ affected by dairy farming system (Table 4), because the values for the cheeses from traditional herds were lower than those from the modern systems (Supplemental Table S1, https://doi .org/10.3168/jds.2019-17829). These differences could be partly explained by the differences that Bittante et al. (2015) found in the coagulation properties of milk from the same cows, which showed that traditional herds exhibited lower values for the instant rate constant of curd syneresis and higher values for maximum curd firmness than the modern systems. Greater expulsion of whey during cheese-making could be responsible for lower water loss during ripening.

Large differences are known to exist among individual herds, and also within dairy system, for milk composition (Ng-Kwai-Hang et al.,1984; Allore et al., 1997), coagulation, and curd firming traits (Stocco et al., 2017), and, consequently, \%CY (Stocco et al., 2018). 
Cipolat-Gotet et al.: MODELING WEIGHT LOSS OF CHEESE DURING RIPENING

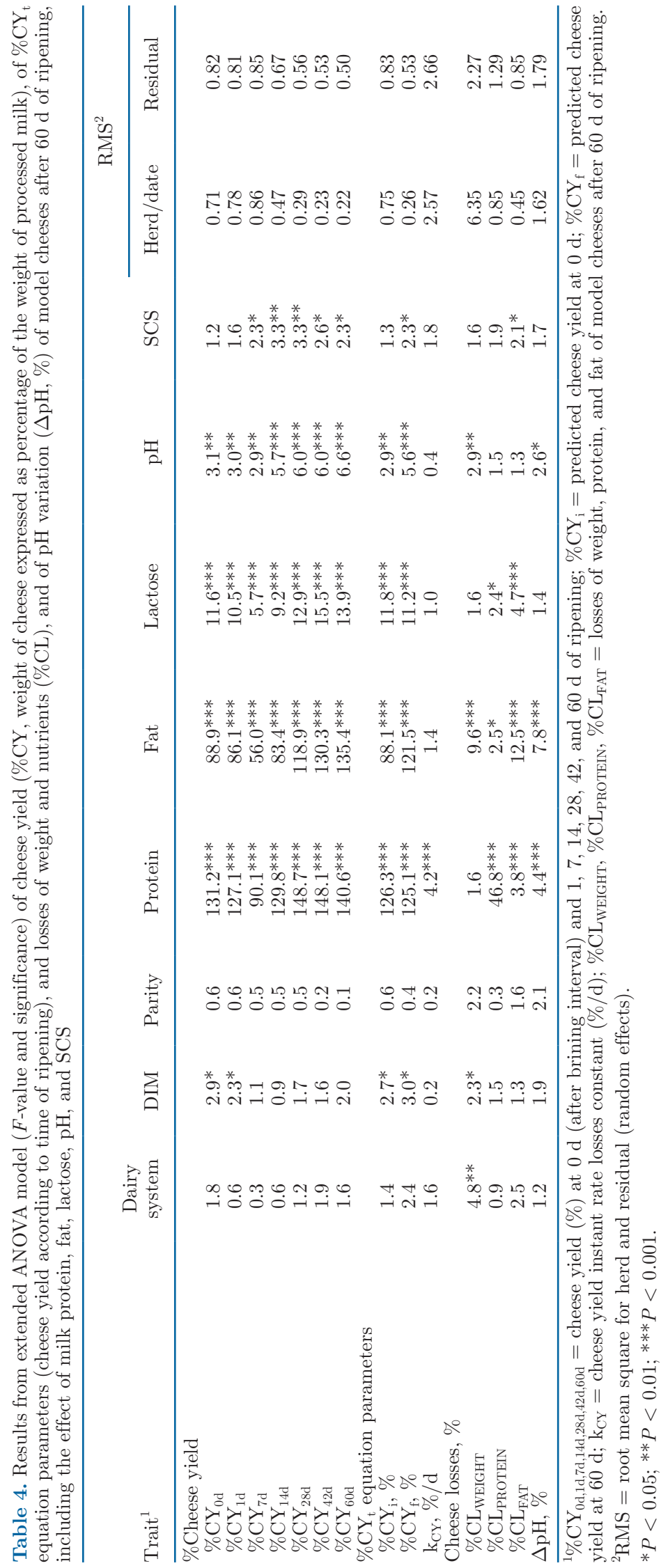



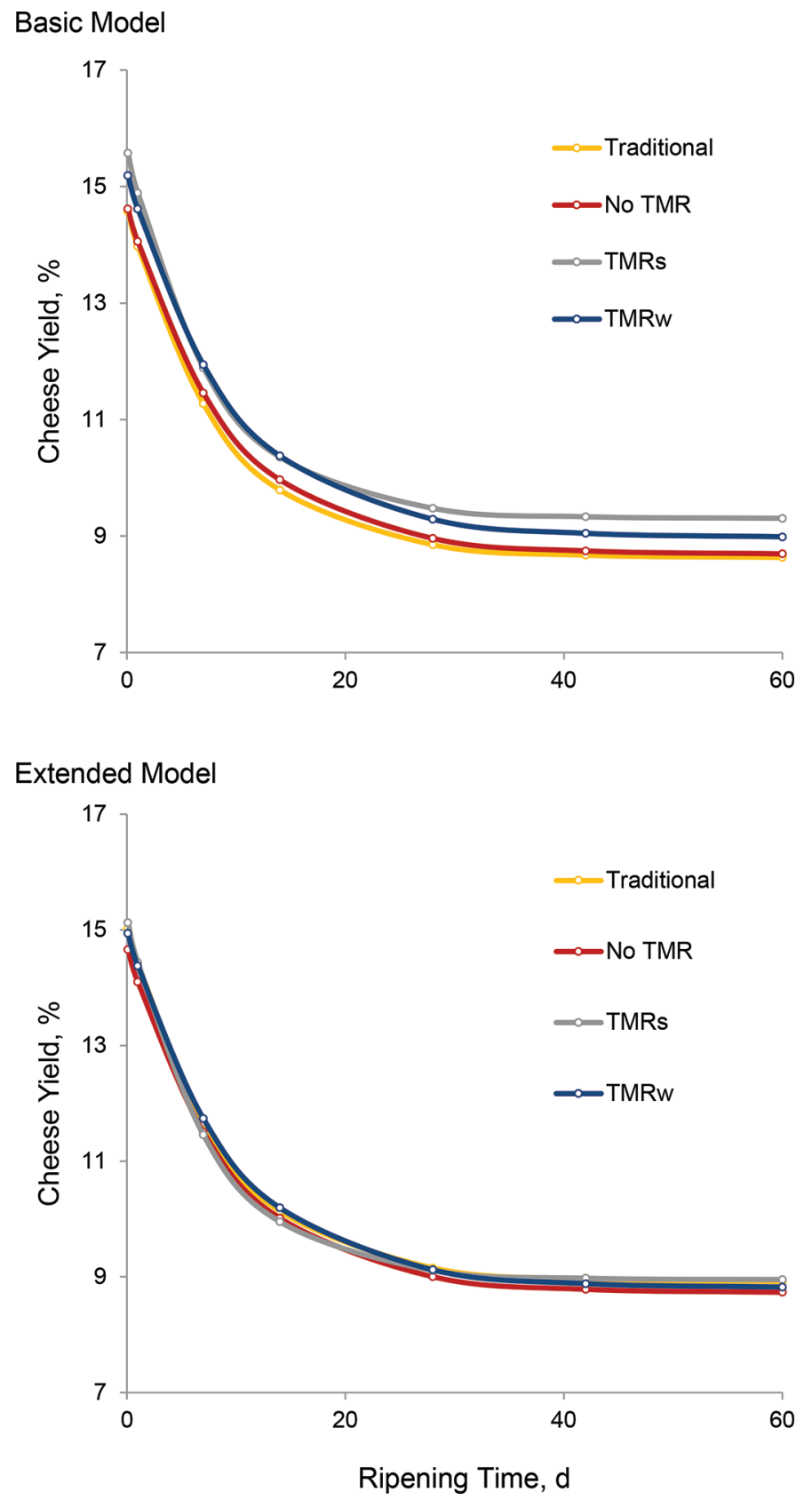

Figure 2. Pattern of $\% \mathrm{CY}_{\mathrm{t}}$ (cheese yield along ripening period) of model cheeses according to basic and extended models for dairy farming systems. Dairy farming systems: Traditional $=$ traditional system with tied animals; No TMR = modern dairy system with traditional feeding based on hay and compound feed; TMRs = modern dairy system with TMR including silage; TMRw $=$ modern dairy system with silage-free TMR (water added for moisture).

We found that the variation among different herds and dates, corrected for all the other factors included in the model, was always smaller than the variation among different cows within herd (residual), regardless of whether milk composition was included in the statisti- cal model (Table 4) or not (Table 3). This was the case for all traits except $\% \mathrm{CL}_{\text {WEIGHT }}$.

\section{Effects of Factors Related to Individual Cows on the Evolution of \%CY During Ripening}

We also found important differences between the basic and extended models in the case of animal factors (DIM and order of parity). Analysis with the basic model revealed both parity and DIM to very significantly $(P<0.01)$ affect 12 of the 14 traits studied (Table 3), whereas with the extended model including milk composition, DIM significantly affected only 5 traits $(P<0.05)$, and parity none (Table 4$)$. Indeed, DIM is expected to have a greater effect on milk composition than parity (Stanton et al., 1992; Vanbergue et al., 2017). Here, too, modeling $\% \mathrm{CY}_{\mathrm{t}}$ confirmed that, after taking milk composition into account in the ANOVA, the differences among cheeses from cows of different parities or lactation stages (Figure 3b and d) became negligible.

\section{Effects of Milk Quality on the Evolution of \%CY During Ripening}

The influence of milk composition on the characteristics of ripened cheese have been extensively investigated (Fox et al., 2017), but less is known of the effect of milk quality on the novel phenotypes related to the evolution of \% CY over time presented in this study. Table 4 reports the $F$-values and significance levels of the effects of milk quality on $\% \mathrm{CY}$, the $\% \mathrm{CY}_{\mathrm{t}}$ modeling equation parameters, \%CL, and $\Delta \mathrm{pH}$ (extended model), and Figure 4 summarizes the patterns of the $\% \mathrm{CY}_{\mathrm{t}}$ equation parameters across classes of milk protein, fat, lactose, $\mathrm{pH}$, and SCS. As expected, milk quality traits, both measured and modeled, greatly affected \%CY during ripening (Table 4). This was especially the case for milk fat and protein, these being the major components of cheese and the major factors affecting cheese yield (Wedholm et al., 2006). In our study, these milk components together accounted for $45.5 \%$ of the total weight of fresh model cheeses and $64.9 \%$ of the total weight of ripened model cheeses (Table 1).

Of all the milk components analyzed, milk protein had the most significant effect on almost all the traits reported in Table 4. Milk protein was expected to have positive linear effects on all $\% \mathrm{CY}$ at specific ripening times, and hence also on $\% \mathrm{CY}_{\mathrm{i}}$ and $\% \mathrm{CY}_{\mathrm{f}}$ (Wedholm et al., 2006; Bonfatti et al., 2019). It is worth noting that protein was the only milk component also affecting $\mathrm{k}_{\mathrm{CY}}$ - that is, affecting the pattern of reduction in 
cheese wheel weight during ripening, which was less pronounced in cheeses made from milk with a high protein content (Guinee et al., 2007). That this weight loss depends not only on cheese moisture losses but also on cheese metabolism during ripening is confirmed by its effects on \%CL $\mathrm{CLRTEIN}_{\text {Prot }}$ and $\mathrm{CL}_{\mathrm{FAT}}$ (Table 4 ). The increase in milk protein content was, in fact, accompanied by lower protein and fat losses during ripening (Supplemental Table S2, https://doi.org/10.3168/jds

\section{Parity - Basic Model}
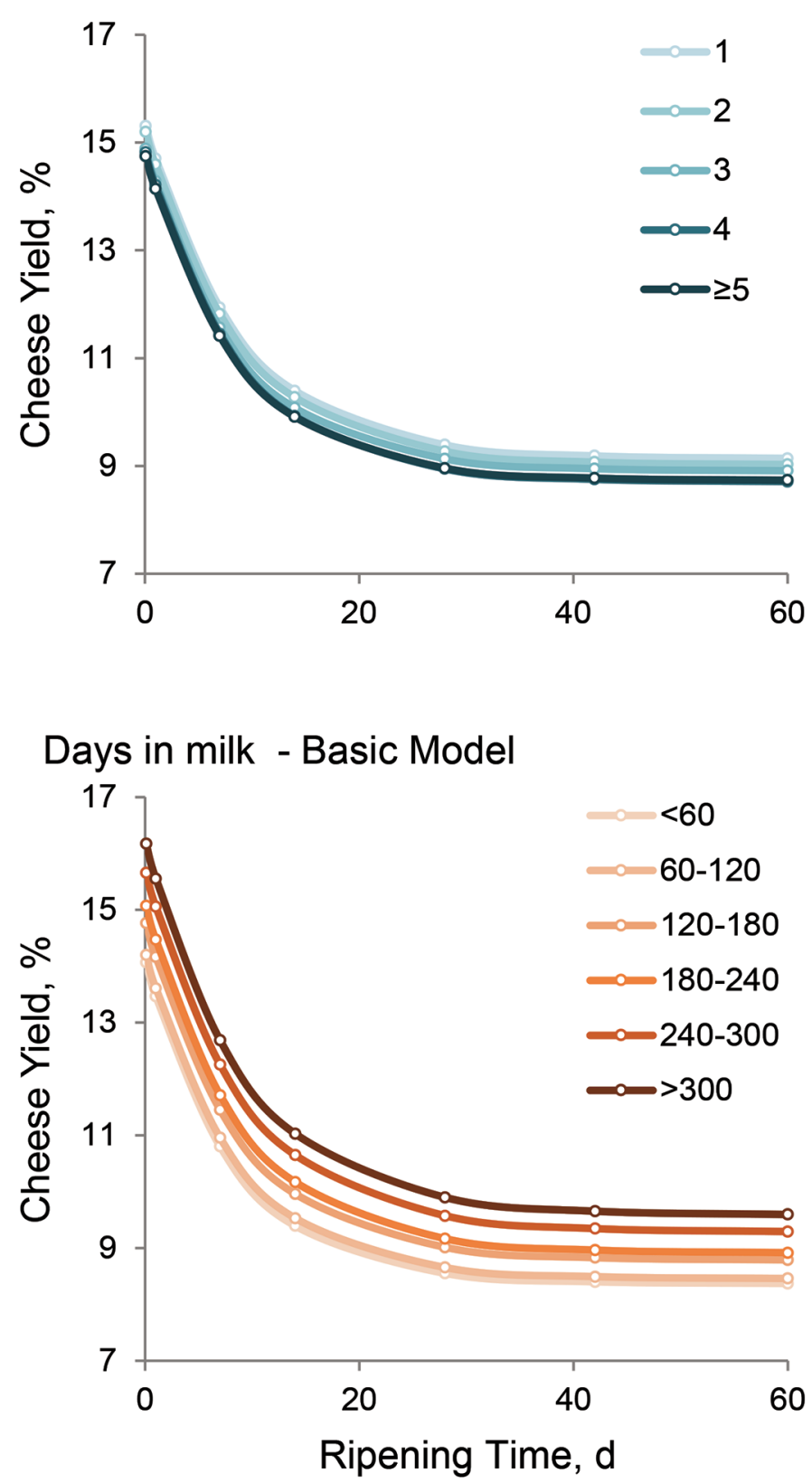

.2019-17829). It is worth noting that milk fat content had an effect on \%CY similar to or greater than that of milk protein (Figure 4) but did not modify the pattern of cheese weight loss over time $\left(\mathrm{k}_{\mathrm{CY}}\right)$. The effect of milk fat content on cheese protein and fat loss during ripening (Table 4) was opposite to the effect of milk protein: a higher milk fat content was associated with higher protein and fat losses in the cheeses during ripening (Supplemental Table S2).
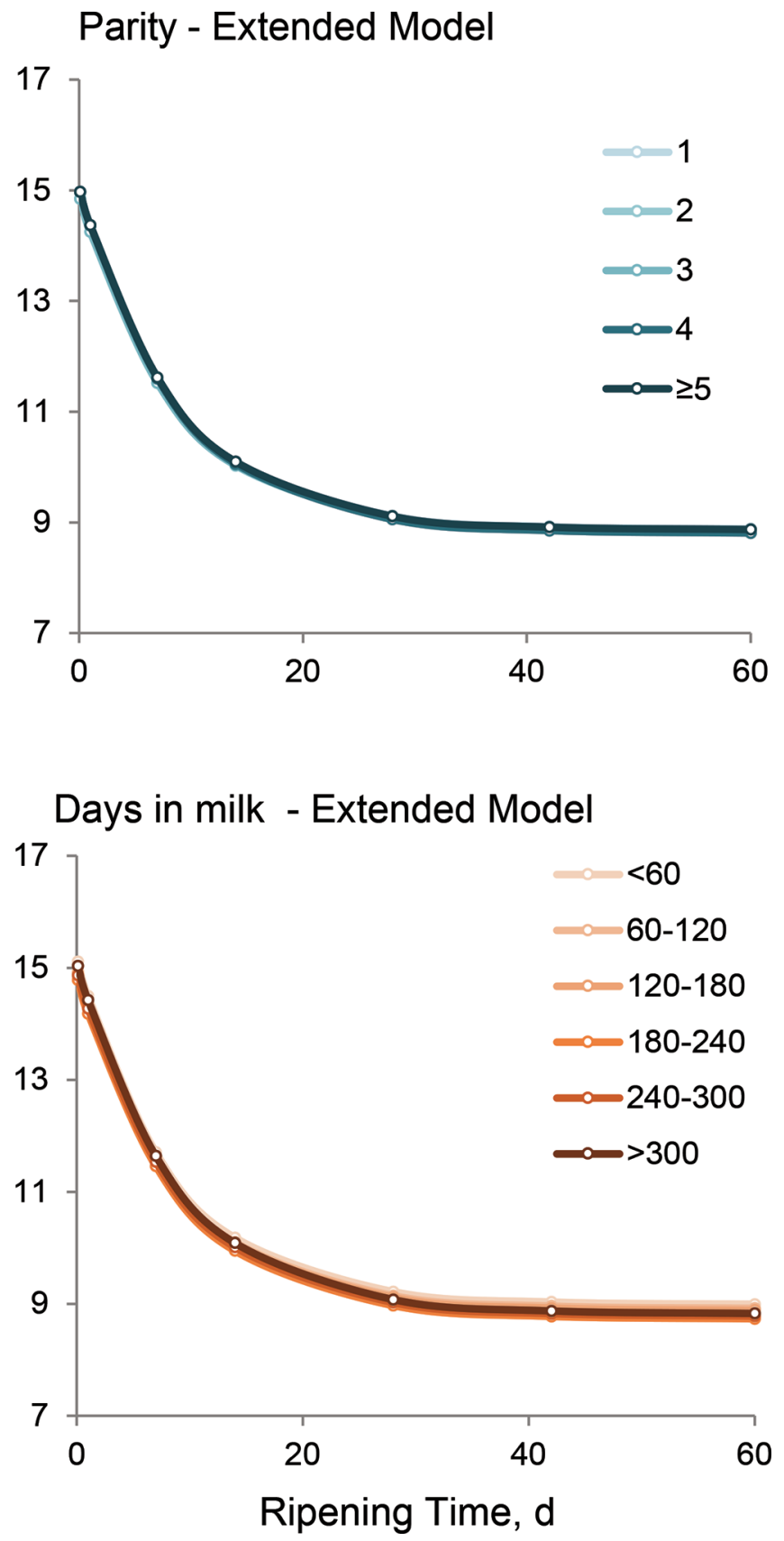

Figure 3. Pattern of $\% \mathrm{CY}_{\mathrm{t}}$ (cheese yield along ripening period) of model cheeses according to basic and extended models for classes of parity and stage of lactation. 
Milk protein

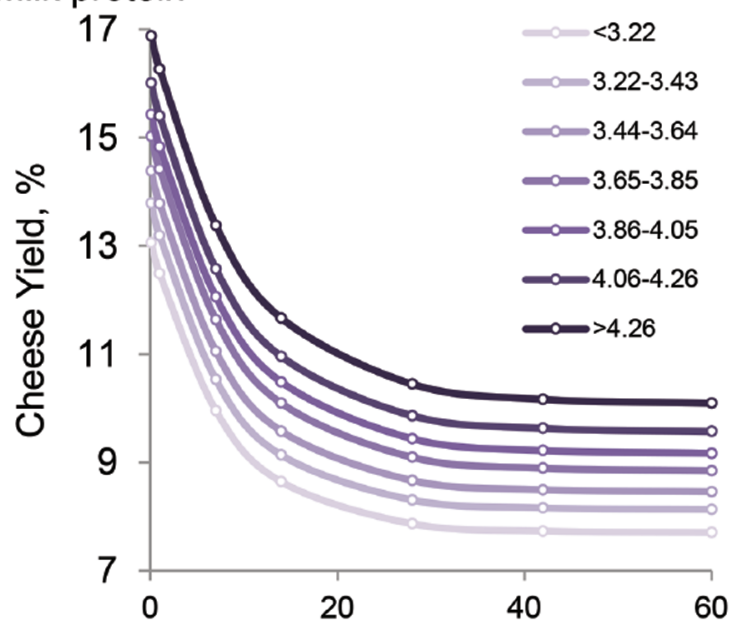

Milk lactose

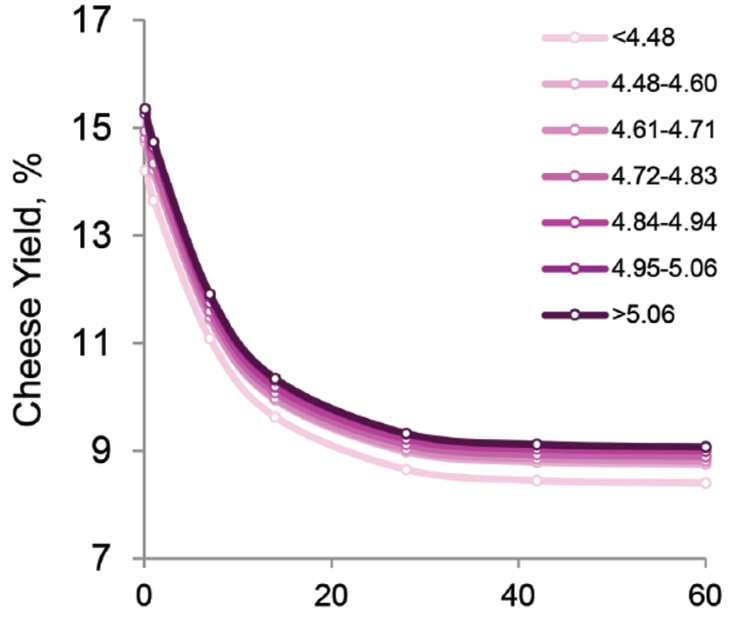

Milk pH

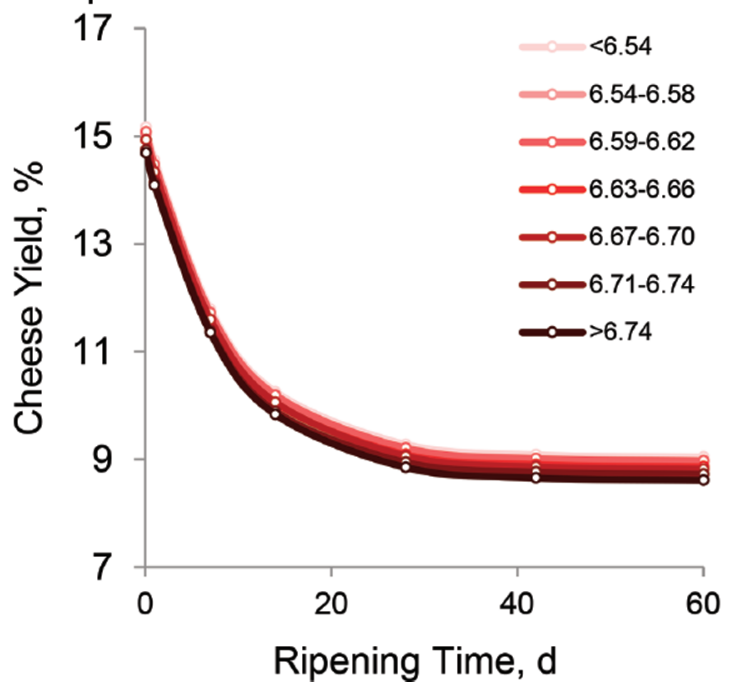

Milk fat

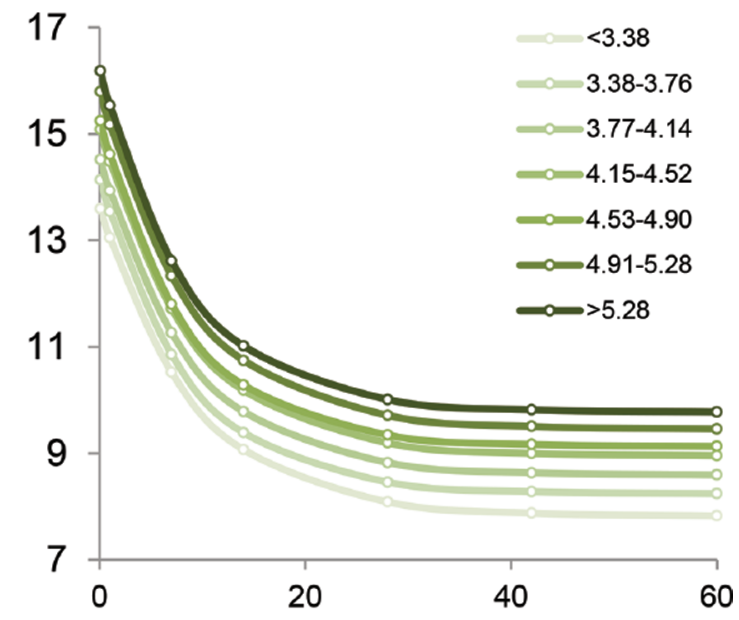

Milk SCS

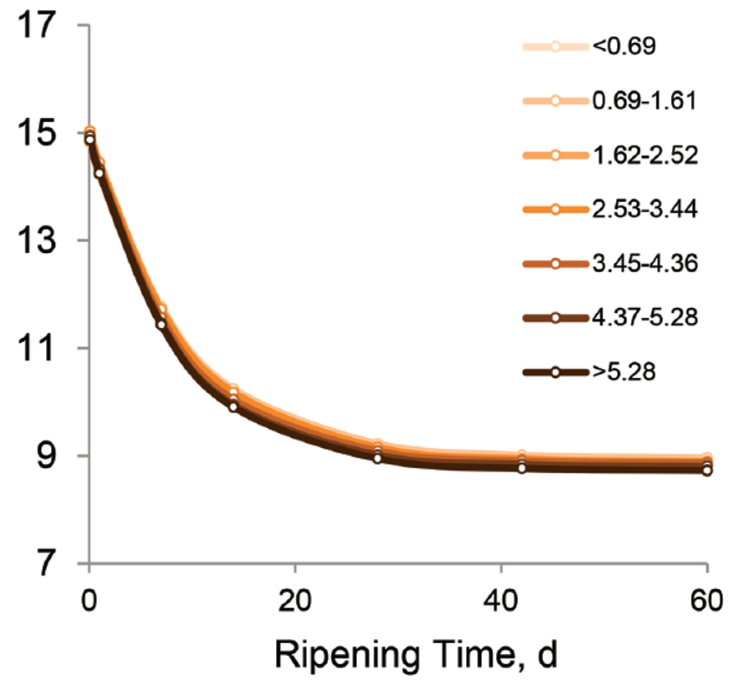

Figure 4. Pattern of $\% \mathrm{CY}_{\mathrm{t}}$ (cheese yield along ripening period) of model cheeses across classes of milk protein, fat, lactose, SCS, and pH. 
Milk lactose, SCS, and $\mathrm{pH}$ are not constituents of cheese, but they are partly correlated with each other (Pazzola et al., 2018) and are often taken as indirect indices of udder health (Bobbo et al., 2016; Stocco et al., 2019). Lactose positively influenced \%CY at each ripening interval as the predicted $\% \mathrm{CY}_{\mathrm{i}}$ and $\% \mathrm{CY}_{\mathrm{f}}$, but not the $\mathrm{k}_{\mathrm{CY}}$ (Table 4). Bearing in mind that the small content of lactose in fresh cheese is rapidly metabolized by the cheese microbiome and by native enzymatic activity (Fox et al., 2017), the favorable effect of lactose on \% $\mathrm{CY}$ is mainly due to a decrease in its content associated with cheese protein and fat losses during ripening (Table 4; Supplemental Table S2, https://doi.org/10.3168/jds.2019-17829). Milk SCS and $\mathrm{pH}$ had less of an effect on the evolution of $\% \mathrm{CY}$ during ripening (Table 4). In fact, increased milk SCS, usually associated with subclinical mastitis, seems to be associated with increased cheese fat losses during ripening, whereas increased milk $\mathrm{pH}$ was associated with increased cheese weight losses, probably because of major moisture losses. These results are in agreement with the results reported by Vacca et al. (2019) for fresh \%CY of sheep milk but contrast with results from Stocco et al. (2019) for goat milk. In our study, the differences among classes of lactose in terms of \%CY were maintained along the entire model cheese ripening period.

These findings are probably related to the effect of $\mathrm{pH}$ during cheese-making. Milk samples with a higher $\mathrm{pH}$ have longer clotting times (Poulsen et al., 2015) and are associated with lower cheese-making efficiency (Sales et al., 2017). We also found a positive relationship between milk and curd $\mathrm{pH}\left(\mathrm{R}^{2}=0.37\right.$; data not shown). When $\mathrm{pH}$ at curd draining is relatively low, chymosin retention is expected to be high, which is why $\alpha_{\mathrm{S} 1}$ casein tends to be more hydrolyzed at a lower curd pH (Holmes et al., 1977). However, we did not observe any effect of milk $\mathrm{pH}$ on $\% \mathrm{CL}_{\text {PRotein }}$. We also assessed $\Delta \mathrm{pH}$ during ripening, as variation in this could directly affect cheese characteristics as a consequence of the effect on the solubility of caseins (McSweeney, 2004). This trait was mostly affected by milk protein and fat, and in those samples with higher contents of these components we observed an increase in $\Delta \mathrm{pH}$.

Last, although milk SCS is frequently associated with a reduction in \%CY and generally lower cheese-making efficiency (Bobbo et al., 2016), we found that SCS had a negligible effect on almost all the traits recorded during model cheese ripening. However, it should be borne in mind that SCS were obtained from a statistical model that also included factors of milk composition, animal, and environment. For these reasons, the effect of SCS was probably absorbed by the effects of $\mathrm{pH}$ and lactose (Stocco et al., 2019).

\section{CONCLUSIONS}

This study has contributed new knowledge and useful tools for improving the monitoring and efficiency of cheese ripening. The proposed model for monitoring cheese yield during ripening ( $\% \mathrm{CY}_{\mathrm{t}}$ equation) has 2 compartments: one that is constant during ripening (identified with the $\% \mathrm{CY}_{\mathrm{f}}$ ), whereas the other is destined to be lost over time, according to a first-order kinetics. The model allowed us to predict \%CY during ripening with excellent accuracy using a few simple pieces of information. It adapted well to milk from cows reared in different dairy farming systems and herds, and at different stages of lactation and parities. Although wide variability exists in the database, the equation model offered a very good fit to the data. The results showed clearly that weight loss in cheese wheels during ripening is not simply a drying phenomenon, but instead reveals a pattern that may be modified by cheese composition. The modeling methodology presented here should be adapted and tested on a wide range of cheese categories and ripening conditions, validated for specific production technologies and optimized in different dairy plants. A possible new application in the dairy industry would see this model used to evaluate the potential of some of these novel traits as indicators in milk quality-based payment systems. Another practical use of these phenotypes at the herd level could be to further investigate their genetic variation, and the use of infrared spectrometry to predict how they relate to cheese ripening needs to be explored.

\section{ACKNOWLEDGMENTS}

The authors have not stated any conflicts of interest.

\section{REFERENCES}

Ali, A. K. A., and G. E. Shook. 1980. An optimum transformation for somatic cell concentration in milk. J. Dairy Sci. 63:487-490. https: //doi.org/10.3168/jds.S0022-0302(80)82959-6.

Allore, H. G., P. A. Oltenacu, and H. N. Erb. 1997. Effects of season, herd size, and geographic region on the composition and quality of milk in the Northeast. J. Dairy Sci. 80:3040-3049. https://doi.org/ 10.3168/jds.S0022-0302(97)76271-4.

Barjolle, D., J. M. Chappuis, and M. Dufour. 2005. Key success factors of competitive position from some protected designation of origin (PDO) cheeses. Pages 245-262 in Indicators of Milk and Beef Quality. J. F. Hocquette and S. Gigli, ed. Wageningen Academic Publishers, Wageningen, the Netherlands.

Bergamaschi, M., E. Aprea, E. Betta, F. Biasioli, C. Cipolat-Gotet, A. Cecchinato, G. Bittante, and F. Gasperi. 2015a. Effects of dairy system, herd within dairy system, and individual cow characteristics on the volatile organic compound profile of ripened model cheeses. J. Dairy Sci. 98:2183-2196. https://doi.org/10.3168/jds .2014-8807.

Bergamaschi, M., F. Biasioli, L. Cappellin, A. Cecchinato, C. CipolatGotet, A. Cornu, F. Gasperi, B. Martin, and G. Bittante. 2015b. Proton transfer reaction time-of-flight mass spectrometry: A high- 
throughput and innovative method to study the influence of dairy system and cow characteristics on the volatile compound fingerprint of cheeses. J. Dairy Sci. 98:8414-8427. https://doi.org/10 3168/jds.2015-9803.

Bittante, G., C. Cipolat-Gotet, and A. Cecchinato. 2013. Genetic parameters of different measures of cheese yield and milk nutrient recovery from an individual model cheese-manufacturing process. J. Dairy Sci. 96:7966-7979. https://doi.org/10.3168/jds.2012-6517.

Bittante, G., C. Cipolat-Gotet, F. Malchiodi, E. Sturaro, F. Tagliapietra, S. Schiavon, and A. Cecchinato. 2015. Effect of dairy farming system, herd, season, parity, and days in milk on modeling of the coagulation, curd firming, and syneresis of bovine milk. J. Dairy Sci. 98:2759-2774. https://doi.org/10.3168/jds.2014-8909.

Bobbo, T., C. Cipolat-Gotet, G. Bittante, and A. Cecchinato. 2016. The nonlinear effect of somatic cell count on milk composition, coagulation properties, curd firmness modeling, cheese yield, and curd nutrient recovery. J. Dairy Sci. 99:5104-5119. https://doi .org/10.3168/jds.2015-10512.

Bonfatti, V., D. Ribeiro de Freitas, A. Lugo, D. Vicario, and P. Carnier. 2019. Effects of the detailed protein composition of milk on curd yield and composition measured by model micro-cheese curd making of individual milk samples. J. Dairy Sci. 102:7863-7873. https://doi.org/10.3168/jds.2018-15743.

Cichoscki, A. J., E. Valduga, A. T. Valduga, M. E. Tornadijo, and J. M. Fresno. 2002. Characterization of Prato cheese, a Brazilian semi-hard cow variety: Evolution of physico-chemical parameters and mineral composition during ripening. Food Control 13:329336. https://doi.org/10.1016/S0956-7135(02)00039-7.

Cipolat-Gotet, C., A. Cecchinato, M. De Marchi, and G. Bittante. 2013. Factors affecting variation of different measures of cheese yield and milk nutrient recovery from an individual model cheesemanufacturing process. J. Dairy Sci. 96:7952-7965. https://doi .org/10.3168/jds.2012-6516.

Cipolat-Gotet, C., A. Cecchinato, M. A. Drake, A. Marangon, B. Martin, and G. Bittante. 2018. From cow to cheese: Novel phenotypes related to the sensory profile of model cheeses from individual cows. J. Dairy Sci. 101:5865-5877. https://doi.org/10.3168/jds .2017-14342.

Corrieu, G., M. N. Leclercq-Perlat, D. Picque, J. P. Canal, and B. Perret. 2018. Local air velocity, a key factor governing the Raclette cheese mass loss in an industrial ripening room. J. Food Eng. 41:e12822. https://doi.org/10.1111/jfpe.12822.

Davis, J. G. 1965. Cheese: Vol. 1, Basic Technology. Churchill Livingstone, London, UK.

Fallico, V., P. L. H. McSweeney, K. J. Siebert, J. Horne, S. Carpino, and G. Licitra. 2004. Chemometric analysis of proteolysis during ripening of Ragusano cheese. J. Dairy Sci. 87:3138-3152. https:// doi.org/10.3168/jds.S0022-0302(04)73449-9.

Formaggioni, P., A. Summer, M. Malacarne, P. Franceschi, and G. Mucchetti. 2015. Italian and Italian-style hard cooked cheeses: Predictive formulas for Parmigiano-Reggiano 24-h cheese yield. Int. Dairy J. 51:52-58. https://doi.org/10.1016/j.idairyj.2015.07 .008 .

Fox, P. F., T. P. Guinee, T. M. Cogan, and P. L. H. McSweeney. 2017. Fundamentals of Cheese Science. 2nd ed. Springer, New York, NY.

Gaucel, S., H. Guillemin, and G. Corrieu. 2012. A generalised model for cheese mass loss determination during ripening. J. Food Eng. 110:109-116. https://doi.org/10.1016/j.jfoodeng.2011.12.002.

Gobbetti, M., E. Neviani, and P. Fox. 2018. The Cheeses of Italy: Science and Technology. Springer, New York, NY.

Green, M. L., and A. S. Grandison. 1993. Secondary (non-enzymatic) phase of rennet coagulation and post-coagulation phenomena. Pages 101-140 in Cheese: Chemistry, Physics and Microbiology. Vol. 1. 2nd ed. P. F. Fox, ed. Aspen, Gaithersburg, MD.

Guinee, T. P., E. O. Mulholland, J. Kelly, and D. J. O. Callaghan. 2007. Effect of protein-to-fat ratio of milk on the composition, manufacturing efficiency, and yield of Cheddar cheese. J. Dairy Sci. 90:110-123. https://doi.org/10.3168/jds.S0022-0302(07)72613 $-9$.

Hélias, A., P. S. Mirade, and G. Corrieu. 2007. Modeling of Camembert-type cheese mass loss in a ripening chamber: Main biological and physical phenomena. J. Dairy Sci. 90:5324-5333. https://doi .org/10.3168/jds.2007-0272.

Holmes, D. G., J. W. Duersch, and C. A. Ernstrom. 1977. Distribution of milk clotting enzymes between curd and whey and their survival during Cheddar cheesemaking. J. Dairy Sci. 60:862-869. https:// doi.org/10.3168/jds.S0022-0302(77)83955-6.

ISO. 2002. Dried milk, dried ice-mixes and processed cheese-Determination of lactose content-Part 1: Enzymatic method utilizing the galactose moiety of the lactose (ISO 5765-1|IDF 79-1). International Organization for Standardization, Geneva, Switzerland.

ISO. 2010. Milk - Determination of fat content-Gravimetric method (ISO 1211|IDF 1). International Organization for Standardization, Geneva, Switzerland.

ISO. 2014. Milk and milk products-Determination of nitrogen content-Part 1: Kjeldahl principle and crude protein calculation (ISO 8968-1|IDF 20-1). International Organization for Standardization, Geneva, Switzerland.

Law, B. A., and A. Y. Tamine, eds. 2010. Technology of Cheesemaking. 2nd ed. Wiley-Blackwell, John Wiley \& Sons Ltd., Chichester, UK.

Malacarne, M., A. Summer, P. Franceschi, P. Formaggioni, M. Pecorari, G. Panari, and P. Mariani. 2009. Free fatty acid profile of Parmigiano-Reggiano cheese throughout ripening: Comparison between the inner and outer regions of the wheel. Int. Dairy J. 19:637-641. https://doi.org/10.1016/j.idairyj.2009.04.004.

Martín-del-Campo, S. T., D. Picque, R. Cosio-Ramirez, and G. Corrieu. 2007. Evaluation of chemical parameters in soft mold-ripened cheese during ripening by mid-infrared spectroscopy. J. Dairy Sci. 90:3018-3027. https://doi.org/10.3168/jds.2006-656.

McSweeney, P. L. H. 2004. Biochemistry of cheese ripening. Int. J. Dairy Technol. 57:127-144. https://doi.org/10.1111/j.1471-0307 2004.00147.x.

McSweeney, P. L. H. 2017. Biochemistry of cheese ripening: Introduction and overview. Pages 379-388 in Cheese: Chemistry, Physics \& Microbiology. Vol. 1: General Aspects. 4th ed. P. L. H. McSweeney, P. F. Fox, P. D. Cotter, and D. W. Everett. Elsevier Science, Amsterdam, the Netherlands.

Ng-Kwai-Hang, K. F., J. F. Hayes, J. E. Moxley, and H. G. Monardes. 1984. Variability of test-day milk production and composition and relation of somatic cell counts with yield and compositional changes of bovine milk. J. Dairy Sci. 67:361-366. https://doi.org/ 10.3168/jds.S0022-0302(84)81309-0.

O'Shea, B. A., T. Uniacke-Lowe, and P. F. Fox. 1996. Objective assessment of Cheddar cheese quality. Int. Dairy J. 6:1135-1147. https:/ /doi.org/10.1016/0958-6946(95)00065-8.

Pazzola, M., C. Cipolat-Gotet, G. Bittante, A. Cecchinato, M. L. Dettori, and G. M. Vacca. 2018. Phenotypic and genetic relationships between indicators of the mammary gland health status and milk composition, coagulation and curd firming in dairy sheep. J. Dairy Sci. 101:3164-3175. https://doi.org/10.3168/jds.2017-13975.

Pham, A., and S. Nakai. 1984. Application of stepwise discriminant analysis to high-pressure liquid chromatography profiles of water extract for judging ripening of Cheddar cheese. J. Dairy Sci. 67:1390-1396. https://doi.org/10.3168/jds.S0022-0302(84)81453 $-8$.

Poulsen, N. A., A. J. Buitenhuis, and L. B. Larsen. 2015. Phenotypic and genetic associations of milk traits with milk coagulation properties. J. Dairy Sci. 98:2079-2087. https://doi.org/10.3168/ jds.2014-7944.

Putranto, A., M. Woo, C. Selomulya, and X. D. Chen. 2018. An accurate account of mass loss during cheese ripening described using the reaction engineering approach (REA)-based model. J. Food Sci. Technol. 53:1397-1404. https://doi.org/10.1111/ijfs.13717.

Riahi, M. H., I. C. Trelea, M. N. Leclercq-Perlat, D. Picque, and G. Corrieu. 2007. Model for changes in weight and dry matter during the ripening of a smear soft cheese under controlled temperature and relative humidity. Int. Dairy J. 17:946-953. https://doi.org/10 .1016/j.idairyj.2006.11.002.

Sales, D. C., A. H. N. Rangel, S. A. Urbano, A. R. Freitas, H. Tonhati, L. P. Novaes, M. I. B. Pereira, and L. H. F. Borba. 2017. Relationship between mozzarella yield and milk composition, processing 
factors, and recovery of whey constituents. J. Dairy Sci. 100:4308 4321. https://doi.org/10.3168/jds.2016-12392.

Santa-María, G., M. Ramos, and J. A. Ordóñez. 1986. Application of linear discriminant analysis to different proteolysis parameters for assessing the ripening of Manchego cheese. Food Chem. 19:225234. https://doi.org/10.1016/0308-8146(86)90072-5.

Schiavon, S., E. Sturaro, F. Tagliapietra, M. Ramanzin, and G. Bittante. 2019. Nitrogen and phosphorus excretion on mountain farms of different dairy systems. Agric. Syst. 168:36-47. https:// doi.org/10.1016/j.agsy.2018.10.006.

Stanton, T. L., L. Jones, R. Everett, and S. Kachman. 1992. Estimating milk, fat, and protein lactation curves with a test day model. J. Dairy Sci. 75:1691-1700. https://doi.org/10.3168/jds.S0022 -0302(92)77926-0.

Stocco, G., C. Cipolat-Gotet, T. Bobbo, A. Cecchinato, and G. Bittante. 2017. Breed of cow and herd productivity affect milk composition and modeling of coagulation, curd firming and syneresis. J. Dairy Sci. 100:129-145. https://doi.org/10.3168/jds.2016-11662.

Stocco, G., C. Cipolat-Gotet, V. Gasparotto, A. Cecchinato, and G. Bittante. 2018. Breed of cow and herd productivity affect milk nutrient recovery in curd, and cheese yield, efficiency and daily production. Animal 12:434-444. https://doi.org/10.1017/ S1751731117001471.

Stocco, G., M. Pazzola, M. L. Dettori, P. Paschino, A. Summer, C. Cipolat-Gotet, and G. M. Vacca. 2019. Effects of indirect indicators of udder health on nutrient recovery and cheese yield traits in goat milk. J. Dairy Sci. 102:8648-8657. https://doi.org/10.3168/ jds.2019-16369.
Vacca, G. M., C. Cipolat-Gotet, P. Paschino, S. Casu, M. G. Usai, G. Bittante, and M. Pazzola. 2019. Variation of milk technological properties in sheep milk: Relationships among composition, coagulation and cheese-making traits. Int. Dairy J. 97:5-14. https://doi .org/10.1016/j.idairyj.2019.05.002.

Vanbergue, E., L. Delaby, J. L. Peyraud, S. Colette, Y. Gallard, and C. Hurtaud. 2017. Effects of breed, feeding system, and lactation stage on milk fat characteristics and spontaneous lipolysis in dairy cows. J. Dairy Sci. 100:4623-4636. https://doi.org/10.3168/ jds.2016-12094.

Walstra, P.. J. T. M. Wouters, and T. J. Geurts. 2006. Dairy Science and Technology. Taylor and Francis, Abingdon, Oxford, UK.

Wedholm, A., L. B. Larsen, H. Lindmark-Mansson, A. H. Karlsson, and A. Andren. 2006. Effect of protein composition on the cheesemaking properties of milk from individual dairy cows. J. Dairy Sci 89:3296-3305. https://doi.org/10.3168/jds.S0022-0302(06)72366 -9 .

\section{ORCIDS}

Claudio Cipolat-Gotet 주 https://orcid.org/0000-0002-2318-4231 Massimo Malacarne 누 https://orcid.org/0000-0003-3329-698X

Andrea Summer (ํ) https://orcid.org/0000-0002-4833-657X

Alessio Cecchinato ๑ https://orcid.org/0000-0003-3518-720X

Giovanni Bittante @ https://orcid.org/0000-0001-7137-7049 